Int. J. Morphol.,

28(1):265-272, 2010

\title{
The Practice of Dissection as Teaching Methodology in Anatomy Applied to Medical Education
}

\author{
La Práctica de la Disección como Metodología de Enseñanza \\ en Anatomía Aplicada a la Educación Médica
}

Tales Alexandre Aversi-Ferreira; Guilherme Nobre Lima do Nascimento; Ivânia Vera; Roselma Lucchese

\begin{abstract}
AVERSI-FERREIRA, T. A.; NASCIMENTO, G. N. L.; VERA, I. \& LUCCHESE, R. The practice of dissection as teaching methodology in anatomy applied to medical education. Int. J. Morphol., 28(1):265-272, 2010.

SUMMARY: In 2003, the UFG Faculty of Medicine, to revamp its educational project, reduced the hourly load of some subjects, among them those of anatomy, which in general leads to eliminate the practice of dissection. This practice is essential for the basic training of students, being then used in other sciences such as pathology. The objective of this study was to compare and link data between groups that made or did not make dissection after the anatomy course. Questionnaires were issued to 86 medical students from the UFG Faculty of Medicine, and from these, 10 made dissection and 76 did not. Analyzing the answers, it was found that both groups recognize the importance of this practice for the knowledge of the anatomy discipline and for future disciplines or their profession. It follows that dissection could help in the consolidation of post-modern paradigm in medical education since it improves the attention and learning of students.
\end{abstract}

KEY WORDS: Teaching; Medical education; Anatomy; Dissection.

\section{INTRODUCTION}

The history of the dissection practice confused over time with anatomy (Montemayor, 2006), and without this basic technique to study this discipline over the years, the other related sciences would not have been developed, or at least not in the way they are known today.

Such historical and conservatives aspects should be remembered or discussed in relation to its permanence and link with the medical teaching, since recently, in Brazil, the need to decrease the hourly load of various disciplines from the health area has been proposed as consolidation of the curriculum reform suggested by the National Curriculum Guidelines (DCN), and in this context, we believe that the history of anatomy with its base in dissection is not being included in these new directions, as occurs with the discipline of human anatomy for the UFG Medical School (Abreu Neto et al., 2003).

One of the problems associated with the decrease of the dissection practice in anatomy classes in Brazil can be associated with what Montemayor reports in Mexico as the lack of teachers able to lead to dissection associated with high costs for the maintenance of corpses and also with their acquisition has led medical schools to choose for alternative methods such as anatomical models and softwares (Bravo \& Inzunza, 1995; Guiraldes \& Mena, 1993).

In the specific case of human anatomy, the withdrawal of the dissection practice is one of the means to reduce the general hourly load of the medical course, as one of the purposes to approach the students to medical practice earlier. This basic/clinical dissociation has generated several criticisms to the training of future doctors about the lack of questioning minds wishing to understand the phenomena with which they will face, unable to adapt their practices to the needs of their communities (Abreu Neto et al.).

In 2003, the UFG (Goiás Federal University) Faculty of Medicine changed its Course Pedagogical Project (PPC), and the main changes in the curriculum were the early integration of students in the basic healthcare network and the increase in the supervised training, reduction of the hourly 
load and creation of certain disciplines as other practical subjects, which according to Abreu Neto et al., led to no changes in the learning of students, because $42 \%$ of teachers felt no difference in relation to these aspects with the deployment of the new DCN and $21 \%$ of them believed that there was a reduction in the attention and learning of students; however, most teachers agreed with the reformulation.

In this context, the objective of this study was (1) to compare data on students who performed dissection as an optional subject of human anatomy with other students who did not perform dissection as regular subject, from the deployment of the new DCN in 2003, (2) to link these data and to verify if the discipline of human anatomy must be sacrificed in terms of hourly load in the deployment of the new DCN for the medical course, and this fact will mean a reduction of the dissection practice. Thus, the hypothesis tested was whether the dissection practice in teaching anatomy improves the attention and learning of students.

\section{MATERIAL AND METHOD}

The study was conducted at the UFG Faculty of Medicine in the city of Goiânia GO, in 2007. Eighty-six students from the third to tenth periods of medicine were subjects in this research.

After signing the Consent Term, they responded a questionnaire that was developed with the help of psychologists specialized in education. The direct responses did not allow subjectivity and some issues are paradoxical for a more acute perception, thus allowing the identification of possible trends in the responses associated with uncontrolled variables. The questionnaire was responded by 10 students who carried out dissection in the discipline of human anatomy (Group 1 - G1) and 76 students who did not perform it (Group 2 - G2). For G1, question 04 was not included in the questionnaire, since these students had performed dissection in the discipline of human anatomy.

The frequency analysis of responses from 1 to 3 was performed and the correlation analysis was applied to calculate the correlation coefficient $(r)$ in its " $t$ " test, considering the hypothesis that the variables are independent for $\mathrm{p}<0.01$.

\section{RESULTS}

In question 1 (Fig. 1), for $50 \%$ of $\mathrm{G} 1$, the modal class is item 2, and $\mathrm{G} 2$ has as modal class item 5 with $\mathrm{r}=0.87$ and "t" = 3. In question 2 (Fig. 2), groups G1 and G2 had as modal class item 2, and it could be observed that items 1 and 2, which indicate that the improvement of learning in using dissection, in percentage, represented $100 \%$ of responses for $\mathrm{G} 1$ and $88.16 \%$ of responses for $\mathrm{G} 2$ with $\mathrm{r}=$ 0.98 and " $\mathrm{t} "=8.53$. For question 3 (Fig. 3), G1 showed 3 modes in general, but response 5 represented $30 \%$ for items 2 and 3, which represents $60 \%$ of positive responses for the general idea "it helps learning." G2 has the same general mode "it helps learning" with $55.27 \%$, and alternatives 2 and 3 accounted for $22.33 \%$ of the total. The $r$ value for the correlation between groups was 0.69 and $" t "=1.91$. For question 4 (Fig. 4), only responded by G1, it should be stressed that items 4 and 5 had $0 \%$, and that all other items showed relevant factors associated with learning and the future perspectives of graduates, including item 6 that received $30 \%$ for items $1,2,3$ and 4 , all together.
Fig. 1. Relative frequencies (\%) of responses of each group of students in relation to alternatives of the question-1: "In the anatomy classes, attended at the previous semesters that more attention was you?". $r=0.87$ and $\mathrm{t}=3$.

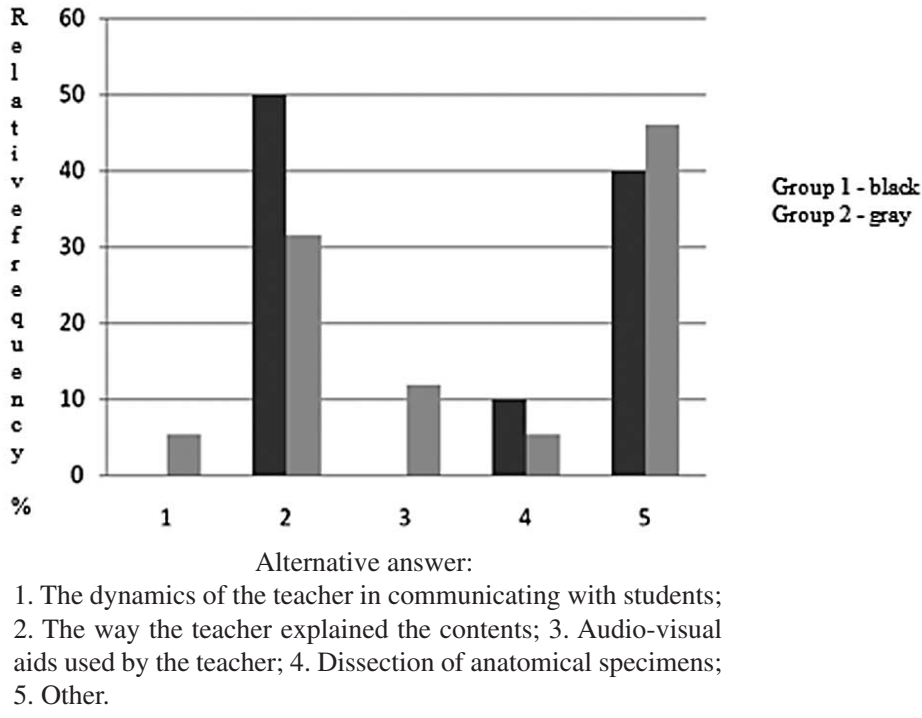


Fig. 2. Relative frequencies (\%) of responses of each group of students in relation to alternatives of the issue-2. "In your opinion, the importance of dissection for learning in Human Anatomy." $\mathrm{r}=0.98$ and $\mathrm{t}=8.53$.

Fig. 3. Relative frequencies $(\%)$ of responses of each group of students in relation to alternatives of the question3. "You attend a discipline that emphasizes only the dissection of human corpses, why?" $\mathrm{r}=0.69, \mathrm{t}=1.91$.

Fig. 4. Relative frequencies (\%) of responses from group 1 in relation to alternatives of the question-4. "What else is calling your attention in the course of dissection of corpses."

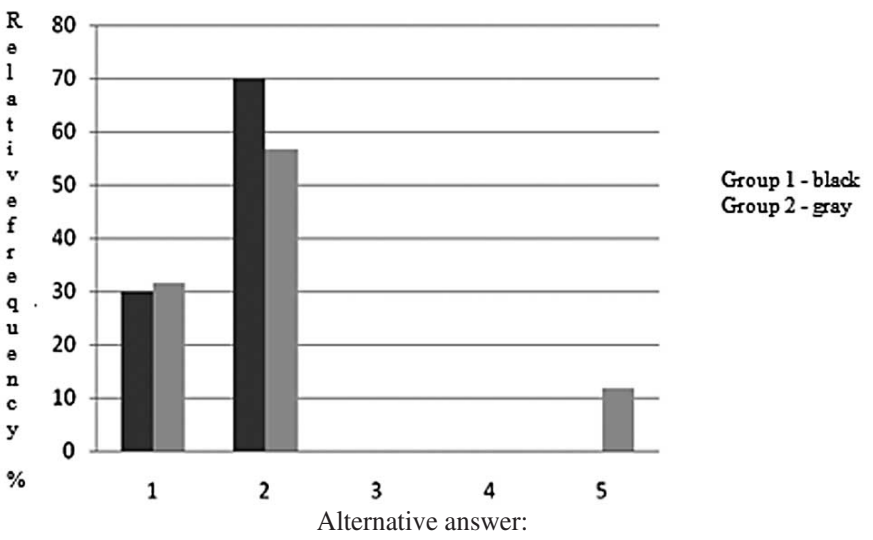

1. Improves learning because the student can see the most realistic for the future acquisition of professional experience; 2 . Improves learning because it enables the formation of mental images closer to the real dynamic structures and facilitates the association between the theoretical concepts and practical; 3 . hinder learning, because the contact with corpses generates behavioral inhibition associated with general fears and ethical aspects; 4. hinder learning, because it helps in the understanding of theoretical concepts; 5 . Other.

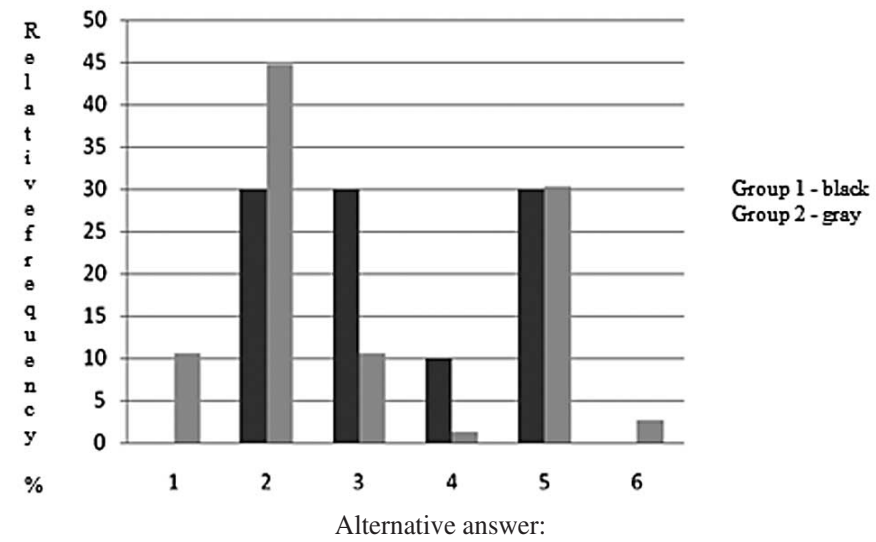

1. did not attend; 2. Helping the learning process in the discipline of Human Anatomy already routed; 3 . Helping my future professional learning; 4. I love to study human anatomy; 5. More than one of the alternatives mentioned above. Which?, 6. Others.

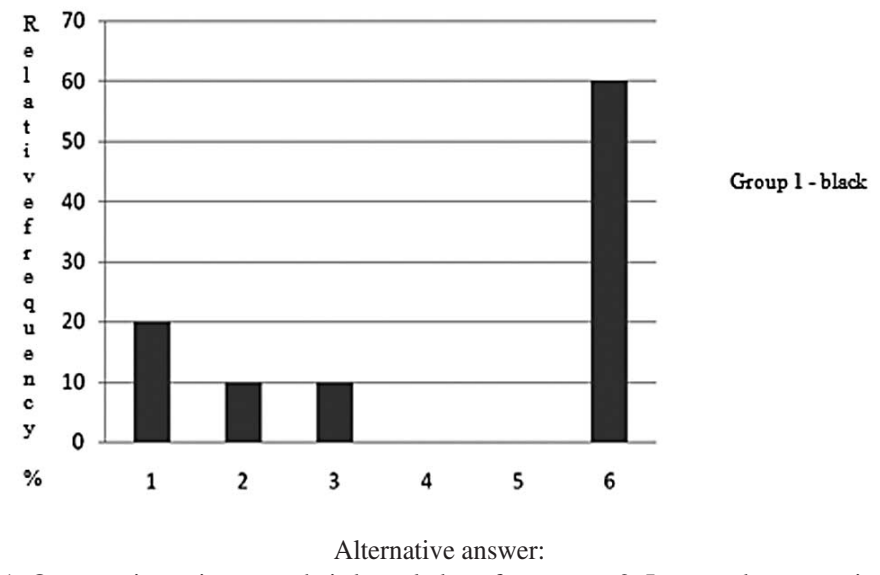

1. Opportunity to improve their knowledge of anatomy; 2. Increased opportunity for professional development; 3. Analysis of organic systems with increased opportunities for interaction with the medical reality; 4 . intimate association between the various systems and tissues by use of topographic anatomy or regional 5 . This course is not holding my attention; 6 . More than one alternative. What? 


\section{DISCUSSION}

In the traditional education paradigm, the higher education teacher teaches, transmits and explains to students the normal science available and then categorize them, and in this case, the good teacher is the good explainer, who knows how to explain difficult things, the emphasis is in the teacher, in the knowledge and its acquisition, generating a distant teacher-student relationship, of superiority of the teacher on the student, making the student to behave passively, only as a receiver of information, therefore, the good student is one who learns throughout the program and answers/plays correctly all the questions on it, drawn up by the keeper of knowledge (Tavares \& Alarcão, 2001).

It should be noted that teaching anatomy has followed this pattern and precept since immemorial times, including the use of dissection.

This form of teaching and learning leads to a conception in which creativity is disfigured, inducing students to impotence before the wisdom of that master who provides the best possible ways to solve early problems.

However, in the post-modern paradigm, students must become aware of their knowledge and behave as active learners, responsible for the building of this knowledge (Tavares \& Alarcão; Novaes, 1999), and it is up for the teacher to encourage them in this sense, assuming the performance of facilitator of the "learning to learn", within the proposal of active pedagogy employed in the new DCN (Ministério da Saúde \& Ministério da Educação, 2007).

Brzezinski (2005) recognizes the importance of helping the student to think, reflect and discover the world transforming their reality. In relation to medical education, Paio (2000) recommends a constructivist approach to the usual model of clinical history as a vital and essential element to consolidate the learning of the Propaedeutic Medical Clinic, according to the objectives for their education, and, according to Fornaziero \& Gil (2003), our options in education should be enlarged without losing sight of the ultimate goal of offering the student the opportunity to build his knowledge with dignity, committed with quality of life and population health.

Skinner (1991) reports that students almost always begin with knowledge by description, and they really learn from the moment they acquire cognitive maturity and realize the need to interact and discover new knowledge. Therefore, in the traditional teaching, the student is not led to the perception of meaningful learning because he is not stimulated to discover, to change.
On the other hand, the theoretical-practical approach in anatomy performing dissection leads the student to understand its applicability in their future profession, provided that the teacher behaves as teacher, mentor, director, intellectual (Moretto \& Mansur, 2000) and also provides psycho-affective involvement from the temporal integrity and scientific curiosity provided by research, otherwise, he will have knowledge within the traditional paradigm. Studies have shown that a good teacher-student relationship leads to a better learning (Ferreira, 2003) and Gonçalves (2001) mentions that the teacher should make a great task, which is to teach that medicine is always at the service of man and that all that science and technology could add will not put this statement into question. The follow up given to the student during dissection is an act that generates proximity with the master, which could be a facilitator of this positive affective relationship, therefore, to restrict or withdraw dissection could lead to decreased opportunities for education that stimulates students to learn to know for themselves as actors of their knowledge.

In this context, the research presented in this article proposes that dissection allows students to be closer to the reality they will face in their work field and that dissection performed in anatomy classes is an important tool for the implementation of education within the postmodern paradigm, and that, according to Montemayor, for the students, dissection is a process that begins with curiosity, as this is frequently their first contact with the physical evidence of death, and it is of general and historical knowledge that dissection has deep roots with anatomy, being a tool for a more complete learning, dissection is the first moment of meeting of the future physician with the realities that will put him at the service of man by meeting with the corpses, which they should respect and care.

Most students who responded the questionnaire believe that dissection makes classes more dynamic and close to the practical context, both by those who had dissection as by those who did not.

From the latter, who were more advanced in the course, the importance of the opinion is even more relevant, since they have more practical experience and possibly experienced real problems in which the lack of anatomical knowledge generated difficulties in medical practice, and this hypothesis is in line with data obtained by Sobral (2002) with medicine students from the University of Brasília (UnB), whose results suggest that the three aspects characteristics of the learner and the learning context are 
related to the change in intensity or frequency of reflections in learning, such that (1) aspects of personal efficacy and self-confidence, (2) aspects of motivation and enhancement of the learning outcomes and (3) aspects of the situation in the course. In this case, only the first two aspects could be observed in our data, because dissection carries initiatives of reflection and self-teaching propensity to acquire further knowledge by medicine students, thus increasing their selfesteem.

On the other hand, dissection is a didactic-teaching technique, and not a discipline itself, therefore, when shorter curricula are considered, the fact of removing this teaching methodology in the discipline of anatomy refers to a dilemmatic discussion on forming "heads that know how to think or heads full of information?" (Perrenoud, 1999). The conflict is to prioritize knowledge in the division of working time in the classroom, since in the curriculum reformulation, there was a need to reduce the hourly load, with consequent maintenance of the content rather than its mobilization in a real context, reducing the dissection practice.

This posture contradicts some evidences of reorientation in the training of health professionals from the Pro-Saúde program (Ministério da Saúde \& Ministério da Educação) as a careful didactic programming with teaching and evaluation methodologies, or the key-concept of pedagogical model that is learning by doing in the actionreflection-action context. The orientation of the integration between basic and clinical cycles is well-preserved, when the practice of dissection in the discipline of anatomy enhances the learning of the pathology knowledge.

Another aspect is that the teaching methodology using dissection, in which the student is the architect of his knowledge, provided that the use of text-books and atlas associated with the display and discovery of structures in the classroom, would bring more joy in relation to learning, since it brings students near the responsibility they will have ahead and helps them to gain attention to work, because the dissection is not a trivial activity.

The constant contact with the didactic material and text-book in the classroom, generating discussion with colleagues, could become something pleasurable to the student (Freitas et al., 2008), and the practical activities would help in learning and cognition in the medicine course, thus stimulating the curiosity and the search is shown as a reinforcement for the learning effectiveness, since summaries and disciplinary contents that consolidate the articulation of the basic sciences with all phases of the professional cycle are necessary (Sobral, 2000), corroborating with the teaching orientation with integration of the basic and professional cycles throughout the course based on issues (Ministério da Saúde \& Ministério da Educação). However, anatomy is the first discipline of the medicine course to create this possibility, and the dissection practice is a strong tool for this to occur.

These aspects become important for the student to acquire knowledge and skills, giving them meaning and mobilizing them in the teaching-learning process in other disciplines and in the construction of the professional being. Schanaider (2002) warns that an inappropriate teachinglearning process may be due to the lack of knowledge of a discipline taught in the first semester of the medicine course, especially when they are needed in the professional cycle.

The curriculum reform implemented in the UFG Faculty of Medicine had and has among other objectives, the training of professionals able to act at different levels of health care, particularly in the primary care (Ciuffo \& Ribeiro, 2008) and with skills to respond to a demand not only specific of his area, but with a comprehensive view of society as a citizen (Lampert, 2002), in an attempt to achieve a teaching model based on new paradigms, guiding the student to be the builder of his own knowledge. Thus, it should be stressed that the withdrawal of dissection from the discipline of anatomy is a nonsense within this new proposal, since anatomy is essential practice to training a physician before contacting the patients, which is in accordance with Teixeira et al. (2001), which, in a study on anatomy-clinical correlations in medical education, reported that the practice of autopsies in the discipline of pathology is a fundamental tool of the anatomy-clinical correlation method and serves to control the quality of care and medical education, therefore, it maintains its value for the development of researches in medicine.

Data obtained in this study showed that students who studied human anatomy by performing dissection considered it important for their learning and their training, and students who did not found that it would be important for their formation and $55.27 \%$ of them indicated that would course an alternative discipline on dissection and this is a strong indicator of the lack of anatomical knowledge reflected in subsequent semesters. In statistical terms, the value of the correlation coefficient calculated showed in all the responses tested that variables G1 and G2 were dependent, which indicates similarity of the choice of alternatives between both groups.

For the opinion of the students surveyed, the dissection of corpses in the discipline of human anatomy is a relevant factor for the professional training, and these data are in line with Abreu Neto et al., which suggest that the 
dissociation of basic education with the clinical cycle has generated more criticism to the medical training, as for its lack of questioning minds, wishing to understand the phenomena with which they will face, unable to adapt their practices to the needs of their communities.

In a more broad reflection and considering that transforming and changing the paradigm is not denying the traditional and hegemonic model, but rather to build the ways of overcoming them. This supports the discussion of data based on this research that agree with at least one of the thoughts of Flexner, considering that the most important for the learning of medicine, from the pedagogical point of view, are the practical activities, both in laboratory and in clinics, fighting, since the first works, education through conferences and learning through simple memorization (Pagliosa \& Da Ros, 2008); however, this case does not intend to debate or inquiry the values of medical education in relation to other aspects, but rather to demonstrate that the practical professional association is ancient concern in the history of medicine.

Therefore, if teaching within the new paradigm must be built by students and teachers, the students were discordant in relation to the loss of the dissection activity in anatomy.

The decrease of the hourly load in health courses in Brazil must be experiencing the same problems as those reported in Mexico (Bravo \& Inzunza; Guiraldes \& Mena).

However, it could be verified that these methods will form a professional more or less prepared to take care of people, because in a critical study on pathology for the medical course made by Athanazio et al. (2009), they considered that the absence of contact with Pathological
Anatomy, or just the inadequate presentation of this discipline creates additional problems of little incentive to the selection of this medical specialty and generates the difficulty of new doctors in dealing with requests and interpretation of anatomy-pathology reports. It should be added that human anatomy is the basis for the pathological anatomy.

Thus, some of the challenges for the training of health professionals especially doctors are brought in that they are prepared to resolve about $80 \%$ to $85 \%$ of health problems encountered in any environment, even for those more precarious of resources. For this, skilled physicians should be prepared in the way of raising the quality of life and health care of people with extensive knowledge of the health-disease process, with self-management and critical of the knowledge/information (Ministério da Saúde \& Ministério da Educação) and it is up to Higher Education Institutions, Health Management, field professionals, teachers and students to be responsible to create spaces for discussion and execution of strategies really effective for the training of this professional, especially to rethink and evaluate the measures already taken.

In conclusion, the data obtained in this article indicate that (1) the use of dissection in anatomy is an important tool for the consolidation of modern paradigms for medical education, a teaching methodology to encourage the critical thinking, investigative and integrator of the basic and clinical knowledge, (2) students who must be part of the discussion of curricular changes, consider that the lack of dissection in anatomy is disadvantageous for their training and for the medical practice in both groups, and finally, (3) the hypothesis assumed that dissection in practical anatomy classes improves the attention and learning of students, was supported by data.

AVERSI-FERREIRA, T. A.; NASCIMENTO, G. N. L.; VERA, I. \& LUCCHESE, R. La práctica de la disección como metodología de enseñanza en anatomía aplicada a la educación médica.Int. J. Morphol., 28(1):265-272, 2010.

RESUMEN: En el 2003, la Facultad de Medicina de la UFG para reformar su proyecto educacional disminuyó la carga horaria de algunos campos, entre ellos la anatomía, lo que en general llevó a eliminar la práctica de la disección. Esta práctica es esencial para el entrenamiento de los estudiantes, que se posteriormente utilizarán en otras ciencias como la patología. El objetivo de este estudio fue comparar y vincular los datos entre los grupos que hicieron o dejaron de hacer disección después del curso de anatomía. Los cuestionarios fueron hechos a 86 estudiantes de la medicina de la UFG, de estos, 10 hicieron disecciones y 76 no las hicieron. Analizando respuestas, se encontró que ambos grupos reconocen la importancia de esta práctica para el conocimiento de la disciplina de anatomía y para disciplinas futuras o incluso su profesión. De esto se deduce de que la disección podría ayudar en la consolidación del paradigma postmoderno en la educación médica, ya que mejora la atención y el aprendizaje del estudiante.

PALABRAS CLAVE: Enseñanza; Educación médica; Anatomia; Disección. 


\section{REFERENCES}

Abreu Neto, I. P.; Lima Filho, O. S.; Silva, L. E. C. \& Costa, N. M. S. C. Percepção dos Professores sobre o Novo Currículo de Graduação da Faculdade de Medicina da UFG Implantado em 2003. Rev. Bras. Educ. Med., 30(3):154-60, 2003.

Athanazio, D. A.; Neves, F. B. C. S.; Bôaventura, C. S. \& Athanazio, P. R. F. O ensino de patologia nas escolas médicas está em crise? Uma revisão sobre a experiência internacional. Rev. Bras. Educ. Med., 33(1):49-54, 2009.

Bravo, H. \& Inzunza, O. Evaluación de algunos programas computacionales en la enseñanzade la Anatomía y Neuroanatomía de la Facultad de Medicina de la Pontificia Universidad Católica de Chile. Rev. Chil. Anat., 13(1):79-86, 1995.

Brzezinsk, I. Qualidade na graduação. Revista Educ. Ativa., $8(2): 321-38,2005$.

Ciuffo, R. S. \& Ribeiro, V. M. B. Brazilian public health system and medical training: possible dialog? Interface (Botucatu), 12(24):25-40, 2008.

Ferreira, M. L. S. M. Avaliação no processo ensinoaprendizagem: uma experiência vivenciada. Rev. Bras. Educ. Med., 27(1):12-9, 2003.

Fornaziero, C. C. \& Gil, C. R. R. Novas tecnologias aplicadas ao ensino da anatomia humana. Rev. Bras. Educ. Med., 27(2):141-6, 2003.

Freitas, L. A. M.; Barroso, H. F. D.; Rodrigues, H. G. \& Aversi-Ferreira, T. A. Construção de modelos embriológicos com material reciclável para uso didático. Biosci. J., 24(1):91-7, 2008.

Gonçalves, E. L. Pedagogia e didática: relações e aplicações no ensino médico. Rev. Bras. Educ. Med., 25(1):20-6, 2001.

Guiraldes, H. \& Mena, B. El uso del software como apoyo para optimizar imágenes morfológicas. Rev. Chil. Anat., 11(2):75, 1993.

Lampert, J. Tendências de mudança na formação médica no Brasil: tipologia das escolas. São Paulo, Hucitec/ ABEM, 2002.

Ministério da Saúde \& Ministério da Educação. Programa
Nacional de Reorientação da Formação Profissional em Saúde - Pró-Saúde: objetivos, implementação e desenvolvimento potencial. (Série C. Projetos, Programas e Relatórios). Brasília, 2007.

Montemayor, F. B. G. El significado de la práctica de disección para los estudiantes de Medicina. Int. J. Morphol., 24(4):575-80, 2006.

Moretto, R. \& Mansur, O. C. Ser professor: as múltiplas dimensões da docência. Rev. Bras. Educ. Med., 24(2):58,2000 .

Novaes, M. H. A convivência em novos espaços e tempos educativos. In: Guzzo, R. S. L. Psicologia escolar. LDB e educação hoje. São Paulo, Editora Alinea, 1999.

Paio, J. M. C. S. Estudo sobre as concepções pedagógicas de docentes das universidades públicas do Rio de Janeiro e desafios para a implementação de uma abordagem construtivista na disciplina clínica propedêutica. Rev. Bras. Educ. Med., 24:76-7, 2000.

Pagliosa, F. L. \& Da Ros, M. A. O relatório Flexner: para o bem e para o mal. Rev. Bras. Educ. Med., 32(4):492-9, 2008.

Perrenoud, P. Construindo as competências desde a escola. Trad. de Bruno Charles Magne. Porto Alegre, Artmed, 1999.

Schanaider, A. Integração das ciências básicas e áreas profissionais no ensino de graduação em medicina. Rev. Bras. Educ. Med., 26(1):67-70, 2002.

Skinner, B. F. Questões recentes na análise comportamental. Campinas, Papirus, 1991.

Sobral, D. T. Reflexão na aprendizagem: análise dos estudantes de um curso de medicina. Rev. Bras. Educ. Med., 26(1):5-12, 2002.

Sobral, D. T. Desenvolvimento de habilidades de aprendizagem: estudo dos efeitos de uma experiência. Rev. Bras. Educ. Med., 24(2):48-54, 2000.

Tavares, J. \& Alarcão, I. Paradigmas de formação $e$ investigação no ensino superior para o terceiro milênio. In: Escola reflexiva e nova racionalidade. Porto alegre, Editora Artmed, 2001. 
AVERSI-FERREIRA, T. A.; NASCIMENTO, G. N. L.; VERA, I. \& LUCCHESE, R. The practice of dissection as teaching methodology in anatomy applied to medical education. Int. J. Morphol., 28(1):265-272, 2010.

Teixeira, M. A. B.; Carvalhal, S. S.; Teixeira, C. O.; Cardoso, M. B. \& Pedro, R. N. Uso do método de correlação anatomoclínica - uma experiência duradoura no ensino médico. Rev. Bras. Educ. Med., 25(3):39-43, 2001.

Correspondence to:

Tales Alexandre Aversi-Ferreira

System Emotional Science

Graduate School of Medicine and

Pharmaceutical Sciences

University of Toyama

Sugitani 2630

Toyama 930-0194

JAPAN

Email: aversiferreira@gmail.com tales@med.u-toyama.ac.jp

Received: 22-08-2009

Accepted: 08-02-2010 